\title{
Geology of the Kayenta and Chilchinbito Quadrangles Navajo County, Arizona
}

GEOLOGICAL SURVEY BULLETIN 1202 -A Prepared in cooperation with the U.S. Bureau of Indian Affairs

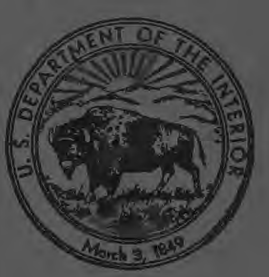




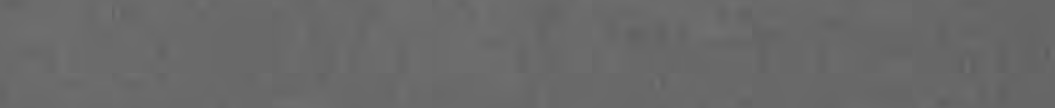

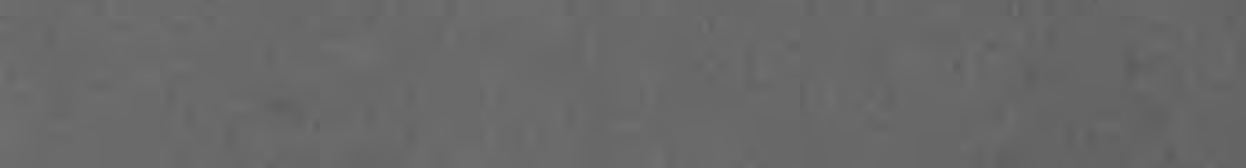

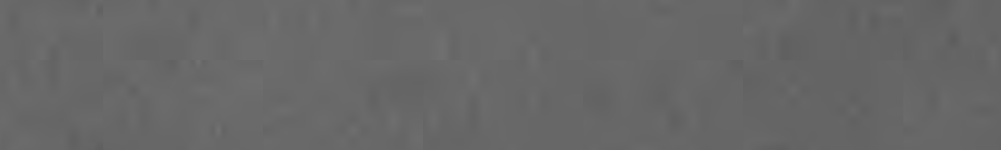

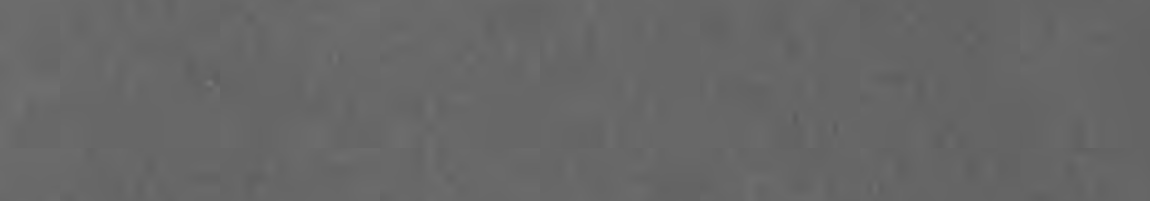

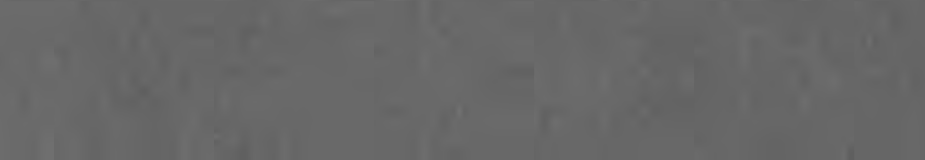

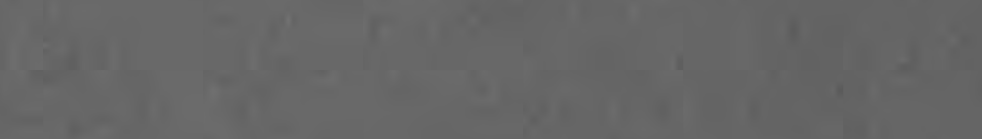

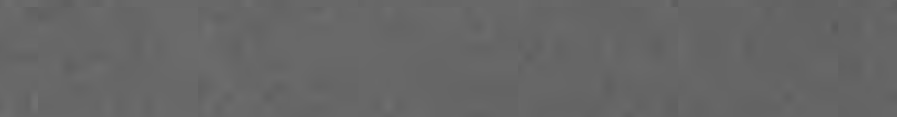

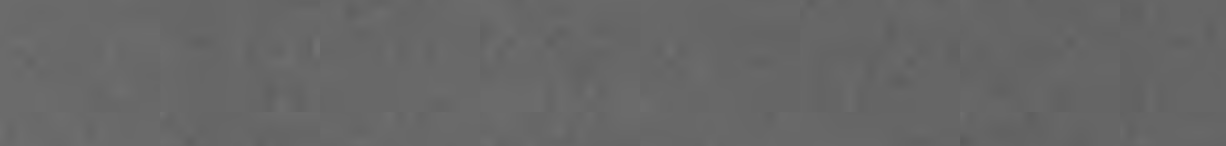

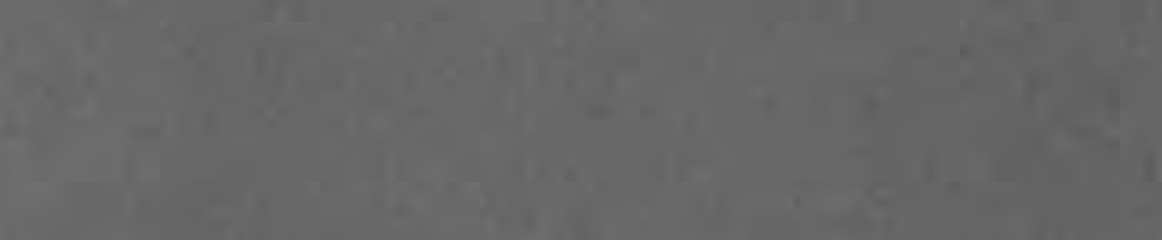

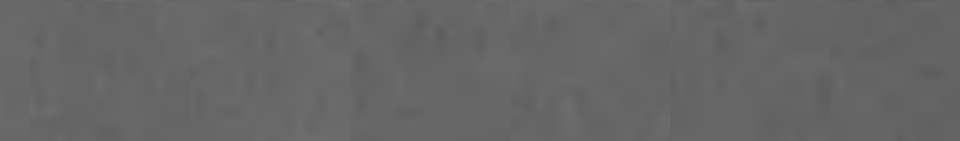

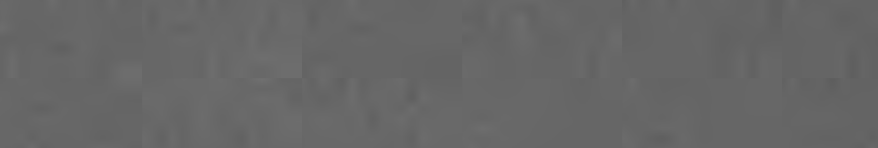

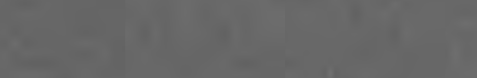

1.t.

$+4$

iftin

$+3$

tats

(17)

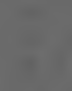

$\sqrt{110}+2$

$-1$

$1+\frac{1}{2}=11$

(1)

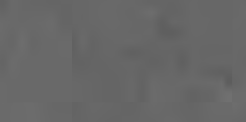

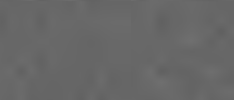

1.

\section{1.}

$x_{1}+11$

1.

(1)

15.

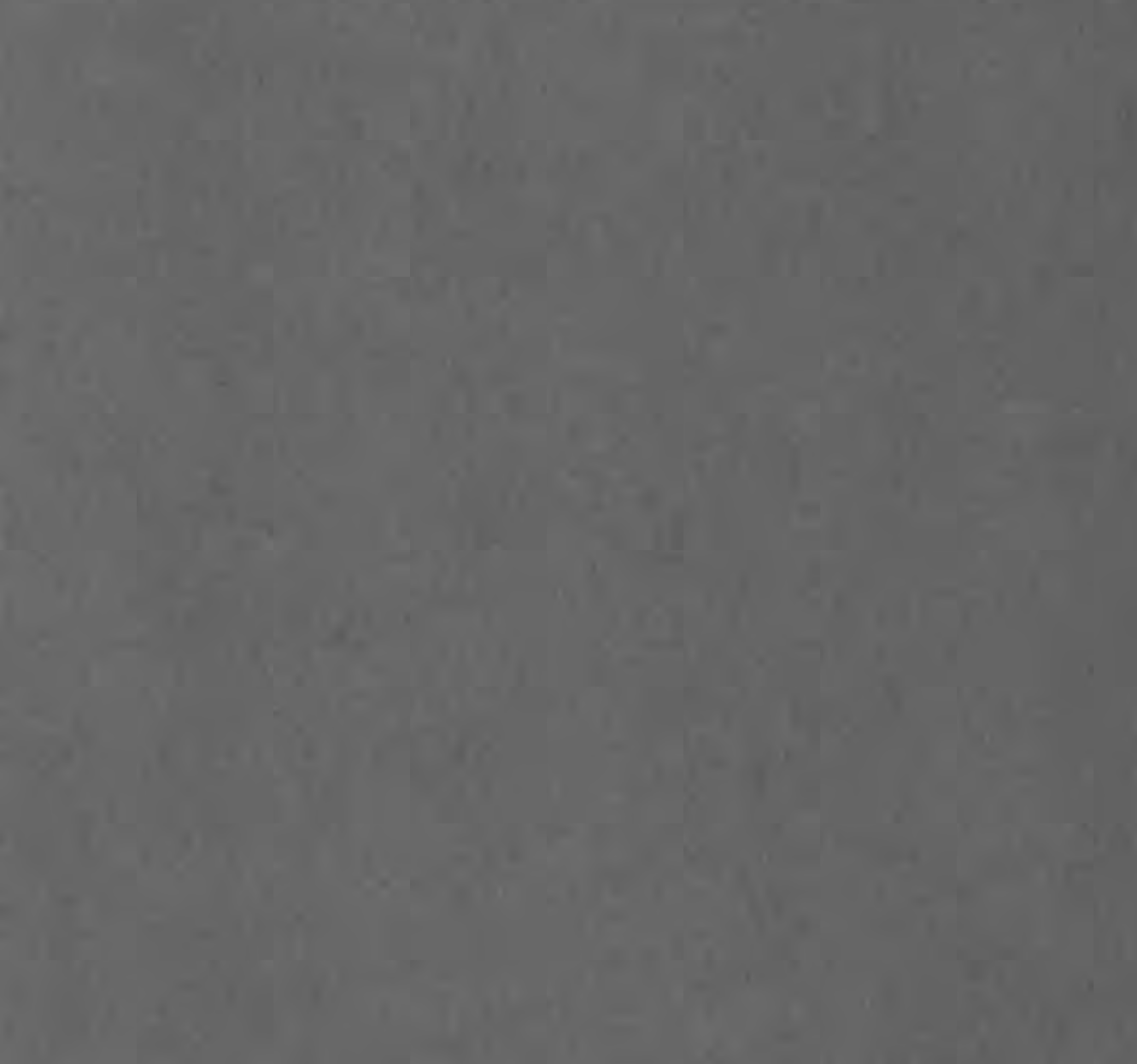




\section{Geology of the Kayenta and Chilchinbito Quadrangles \\ Navajo County, Arizona}

By E. C. BEAUMONT and G. H. DIXON

CONTRIBUTIONS TO ECONOMIC GEOLOGY

GE OLOGICAL SURVEY B ULLE T I N $1202-\mathrm{A}$

Prepared in cooperation with the

U.S. Bureau of Indian Affairs 
UNITED STATES DEPARTMENT OF THE INTERIOR STEWAR'T L. UDALL, Secretary

\section{GEOLOGICAL SURVEY}

Thomas B. Nolan, Director 


\section{CONTENTS}

\begin{tabular}{|c|c|}
\hline \multirow{2}{*}{\multicolumn{2}{|c|}{ Abstract. }} \\
\hline & A1 \\
\hline Introduction & 1 \\
\hline Location and fieldwork & $\mathbf{1}$ \\
\hline Previous work & 2 \\
\hline Geography $\ldots$ & \\
\hline edimentary rocks. & \\
\hline Triassic rocks & \\
\hline Chinle Formation & \\
\hline Triassic, Triassic(?), and Jurassic rocks & 6 \\
\hline Glen Canyon Group & 6 \\
\hline Wingate Sandstone & 6 \\
\hline Kayenta Formation $\ldots$ & \\
\hline Navajo Sandstone & \\
\hline Jurassic rocks & 8 \\
\hline San Rafael Group & 8 \\
\hline Carmel Formation & \\
\hline Entrada Sandstone & 9 \\
\hline Summerville Formation & 10 \\
\hline Cow Springs Sandstone & 11 \\
\hline Morrison Formation & 11 \\
\hline Cretaceous rocks & 13 \\
\hline Dakota Sandstone. & 13 \\
\hline Mancos Shale. & 14 \\
\hline Mesaverde Group & 15 \\
\hline Toreva Formation & 15 \\
\hline Wepo Formation & 16 \\
\hline Yale Point Sandstone & 17 \\
\hline Igneous rocks & 17 \\
\hline Black Rock & 17 \\
\hline Church Rock & 18 \\
\hline es & 18 \\
\hline Chilchinbito Rock & 18 \\
\hline Structural features & 19 \\
\hline Black Mesa basin & 19 \\
\hline Organ Rock monocline and nearby folds & 19 \\
\hline Comb monocline and OJjeto syncline & 19 \\
\hline Kayenta anticline and adjacent folds & 20 \\
\hline cline & 20 \\
\hline Buried Hogan dome and Red Point Mesa anticline & 20 \\
\hline Rough Rock anticline. & 20 \\
\hline Chilchinbito terrace & 21 \\
\hline Age of folding & 21 \\
\hline Oil and gas possibilities. & 21 \\
\hline & 23 \\
\hline Selected references. & 26 \\
\hline
\end{tabular}




\section{ILLUSTRATIONS}

[Plates are in pocket]

Plate 1. Geologic map of the Kayenta and Chilchinbito quadrangles.

2. Diagram showing stratigraphic sections in and adjacent to the Kayenta and Chilchinbito quadrangles.

3. Generalized stratigraphic sections of Paleozoic rocks.

Figure 1. Index map showing location of the Kayenta and Chilchinbito quadrangles.

Page

2. Chart showing sedimentary rocks exposed in the Kayenta and

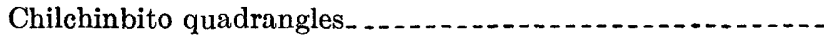

3. Columnar sections of coal beds in Dakota Sandstone and Wepo

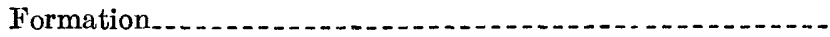

TABLE

TABLE 1. Wells drilled in areas adjacent to the Kayenta and Chilchinbito

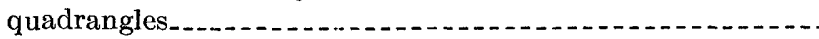




\title{
CONTRIBUTIONS TO ECONOMIC GEOLOGY
}

\section{GEOLOGY OF THE KAYENTA AND GHILGHINBITO QUADRANGLES, NAVAJO GOUNTY, ARIZONA}

\author{
By E. C. Beaumont and G. H. Dixon
}

\begin{abstract}
The Kayenta and Chilchinbito 15-minute quadrangles in northern Navajo County, Ariz., cover about 500 square miles, mostly in the northern part of the Black Mesa basin of northeastern Arizona but including the north end of Black Mesa.

Sedimentary rocks exposed in the quadrangles are approximately 4,600 feet thick and are Triassic, Jurassic, and Cretaceous in age. In ascending order, the formations exposed in the area are the Chinle Formation and Wingate Sandstone of Triassic age; the Kayenta Formation of Triassic (?) age; the Navajo Sandstone of Triassic(?) and Jurassic age; the Carmel Formation, Entrada Sandstone, Summerville Formation, and Morrison Formation of Jurassic age; and the Dakota Sandstone, Mancos Shale, Toreva Formation, Wepo Formation, and Yale Point Sandstone of Cretaceous age. Tertiary intrusive igneous bodies are present in four places.

Through 1963 no exploratory drilling for oil and gas had been done within the Kayenta and Chilchinbito quadrangles nor has it been very extensive in surrounding areas, but structural and stratigraphic data indicate that possible reservoir rocks of Paleozoic age underlie the report area.

Coal is present in the Dakota Sandstone and the Wepo Formation. In the Dakota the coal is not economically valuable, but in the Wepo it has been mined at two localities in the report area.
\end{abstract}

\section{INTRODUCTION}

\section{LOCATION AND FIELDWORK}

The Kayenta and Chilchinbito quadrangles, in the north-central part of the Navajo Indian Reservation, Navajo County, Ariz. (fig. 1), cover about 500 square miles bounded by lats $36^{\circ} 30^{\prime} \mathrm{N}$. and $36^{\circ} 45^{\prime} \mathrm{N}$. and longs $110^{\circ} 00^{\prime} \mathrm{W}$. and $110^{\circ} 30^{\prime} \mathrm{W}$.

Geologic mapping of the area was part of a larger program to assess the fuels potential of the Navajo Indian Reservation. The work was done in cooperation with the U.S. Bureau of Indian Affairs.

The geology (pl. 1) was plotted on aerial photographs and was transferred, by use of a stereographic plotter, to the base map which 


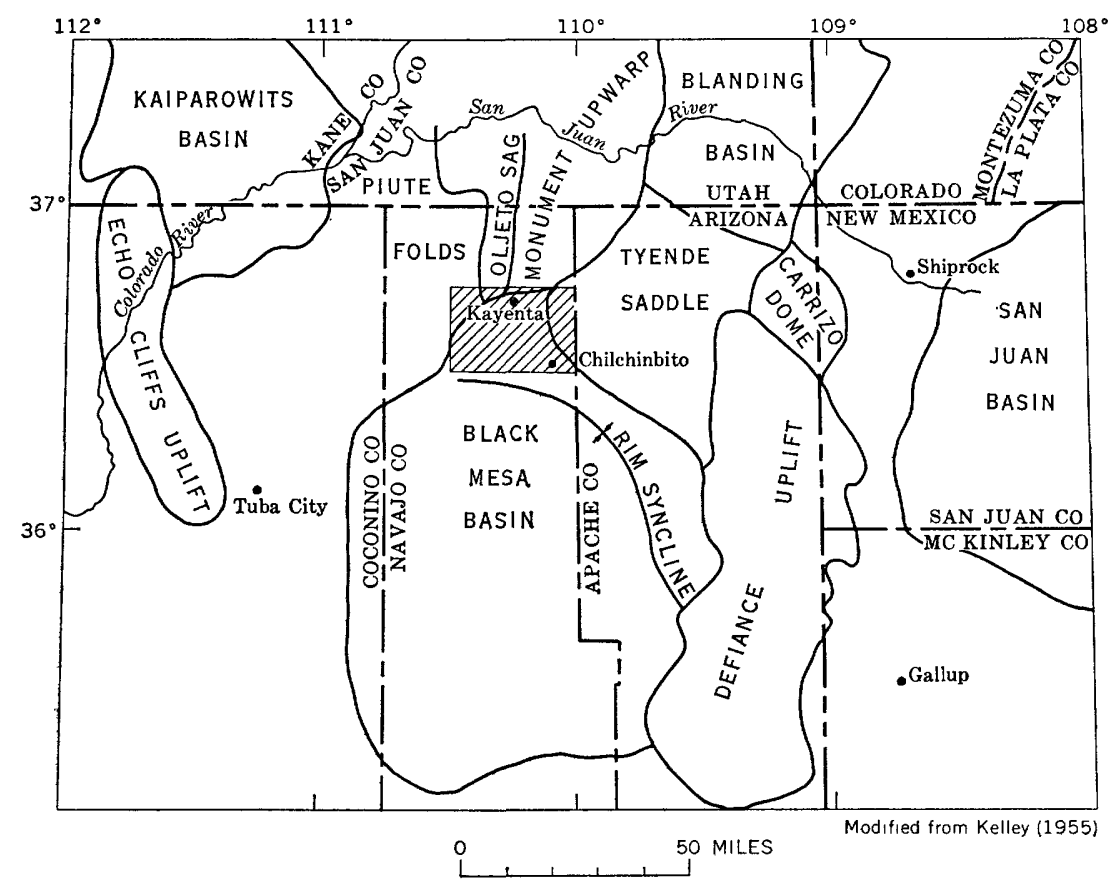

Frgure 1.-Location of Kayenta and Chilchinbito quadrangles and major structural divisions in northeastern Arizona and adjacent areas.

was prepared photogrammetrically from aerial photographs. The Chilchinbito quadrangle was mapped by E. C. Beaumont in the fall of 1955 and the spring of 1956. The Kayenta quadrangle was mapped by G. H. Dixon, assisted by J. F. Fallis, in the spring of 1956. Stratigraphic studies were made by Beaumont, assisted by J. H. Beard, in the summer of 1957.

\section{PREVIOUS WORK}

The report area was studied by Gregory (1917) as part of his geologic reconnaissance of the Navajo country, but the scale of his map including the area was too small $(1: 500,000)$ to show the stratigraphic units in detail. Maps at a scale of $1: 31,680$ are included in more recent reports by Repenning and Irwin (1955) and by Irwin, Repenning, and Stevens (1955), but they do not differentiate some of the stratigraphic units that are shown on plate 1 of the present report. The correlation and age of Cretaceous rocks in the Black Mesa basin were discussed by Reeside and Baker (1929) and by Repenning and Page (1956). The Jurassic and Triassic rocks exposed in the area were subdivided and correlated by Baker, Dane, and Reeside (1936; 
1947) and by Harshbarger, Repenning, and Irwin (1957). The regional stratigraphy of the Morrison Formation was briefly discussed by Craig and others (1955).

\section{GEOGRAPHY}

The dominant geographic feature in the Kayenta and Chilchinbito quadrangles is a high, dissected, southwestward-sloping plateau that extends from the southwestern part of the map area southeastward for many miles. This plateau is forested with piñon pine, juniper, and ponderosa pine. It comprises the north end of Black Mesa and has a steep north- and northeastward-facing escarpment. The highest point on the mesa in the map area is more than 8,000 feet above sea level. Streams draining the mesa on the southwest flow southward into the Little Colorado River, and those on the north and northeast flow generally northward to the San Juan River.

High, steplike mesas cut by steep-walled canyons are in the extreme northwest corner of the area. To the east and southeast these mesas give way to a series of nearly circular reentrants cut into the spectacular dip slopes along the southeast flank of the Organ Rock monocline. This rugged area is separated from Black Mesa by Marsh Pass and Longhouse Valley. The cliffs and canyon bottoms are virtually bare, but the higher country is moderately vegetated. The deepest canyon is Tsegi Canyon through which flows Laguna Creek, the major drainage and the only perennial stream in the map area. Tyende Wash, in the eastern part of the Chilchinbito quadrangle, is the only other major intermittent stream.

The west-central and eastern parts of the area have relatively low relief and are characterized by wide, flat valleys separated by low mesas. Vegetation consists mainly of grasses and low shrubs and is generally sparse. Altitudes average about 5,000 feet.

The town of Kayenta in the north-central part, Tsegi trading post in the west-central part, and Chilchinbito in the southeastern part are the only settlements. Paved roads enter Kayenta from the southwest, north, and northeast; a graded road extends from Kayenta to Chilchinbito and southeastward; and a few dirt roads and trails provide access to the area.

\section{SEDIMENTARY ROCKS}

As much as 4,600 feet of sedimentary rocks, ranging in age from Late Triassic to Late Cretaceous, is exposed in the report area (fig. 2). Quaternary surficial deposits of alluvium, dune sand, and landslide debris are not shown in figure 2. Graphic sections of several of the units at 20 localities in and adjacent to the report area are shown on plate 2. 


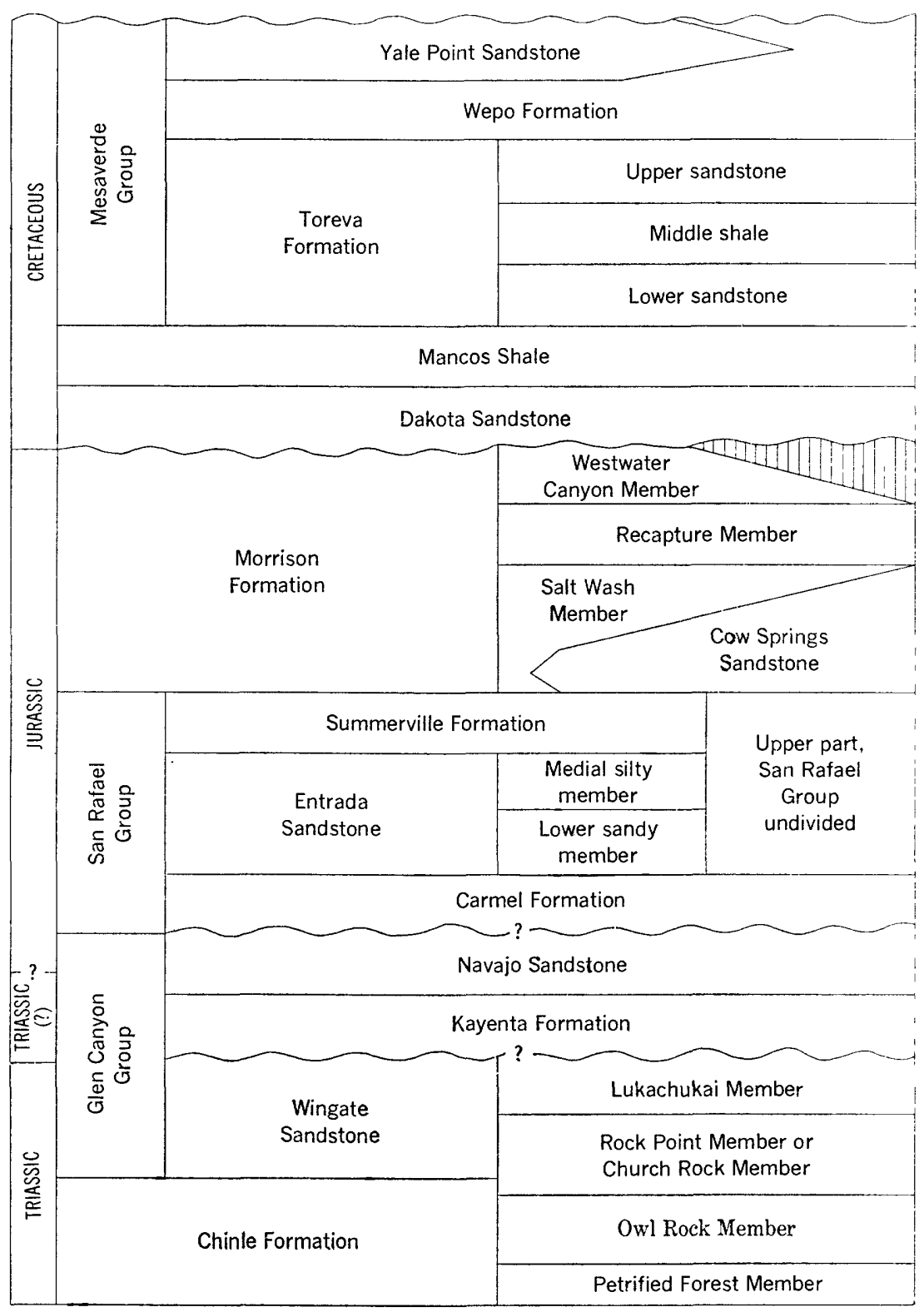

FradRm 2.-Sedimentary rocks exposed in the Kayenta and Chilchinbito quadrangles. 


\section{TRIASSIC ROCKS}

\section{CHINLE FORMATION}

The Chinle Formation of Triassic age is widespread on the Colorado Plateau. In Monument Valley just north of the report area the Chinle consists of five members, which are, in ascending order, the Shinarump, Monitor Butte, Petrified Forest, Owl Rock, and Church Rock. Only the upper three members are exposed in the Kayenta and Chilchinbito quadrangles.

Petrified Forest Member.-The Petrified Forest Member, the oldest exposed rock unit in the report area, is partly exposed in a small area north of Laguna Creek near Kayenta and at two places north of the Tsegi trading post. The member consists of red, purple, and greenishgray bentonitic claystone, clayey sandstone, and mudstone. It is nonresistant and forms slopes. We did not measure the member, but it reportedly is 500-700 feet thick in Monument Valley (Stewart, 1957, p. 457), and it is known to be about 500 feet thick on the flanks of Skeleton Mesa, immediately north of the report area (Witkind and others, 1957a, d).

The Petrified Forest Member is considered Late Triassic in age (Stewart, 1957, fig. 4), and it corresponds to the C division of the Chinle Formation as described by Gregory (1917, p. 43; Stewart, 1957, p. 458).

Owl Rock Member.-The Owl Rock Member is composed of reddishbrown siltstone and mudstone and lesser amounts of greenish-gray claystone, limestone, and limestone-pebble conglomerate. The limestone beds are resistant and at many places form ledges and cuestas. North of Kayenta the member is about 150 feet thick and is conformable on the underlying Petrified Forest Member (Stewart, 1957, p. $458)$.

The Owl Rock is assigned a Late Triassic age (Stewart, 1957, fig. 4). It corresponds to the B division of the Chinle Formation as described by Gregory (1917; Stewart, 1957, p. 458).

Church Rock Member.-The Church Rock Member, the uppermost member of the Chinle, consists of siltstone, mudstone, and thin to medium beds of very fine grained sandstone and silty sandstone. It is uniformly brownish red, except for scattered small leached white spots and streaks. The Church Rock is generally nonresistant, but some beds of more resistant sandstone give it a banded appearance. The more resistant beds appear to be lithologically identical with the softer beds, except for more abundant cementing material. In the vicinity of Kayenta the Church Rock is 195 feet thick; at Marsh Pass, a fer miles to the southwest, it is only 85 feet thick. 
The base of the Church Rock is arbitrarily placed at the top of the highest limestone or limestone-pebble conglomerate in the underlying Owl Rock Member. The contact appears to be virtually conformable, although a zone of reworked limestone pebbles is locally found at the top of the Owl Rock. If a depositional break occurred, it probably was insignificant (Harshbarger, Repenning, and Irwin, 1957, p. 9).

The Church Rock Member is Late Triassic in age. The Rock Point Member of the Wingate Sandstone, which is exposed south of Laguna Creek, occupies the same stratigraphic interval as the Church Rock and is considered (Harshbarger, Repenning, and Irwin, 1957, p. 8-9, 32) to be Late Triassic in age and to correspond to the upper member of the Chinle Formation, division A of Gregory (1917, p. 42). North of Laguna Creek the rocks in the stratigraphic interval occupied by the Rock Point have been called the Church Rock Member of the Chinle (Stewart, 1957, p. 459-460; Witkind and Thaden, 1963, p. 32-34).

\section{TRIASSIC, TRIASSIC(?), AND JURASSIC ROCKS}

\section{GLEN CANYON GROUP}

The Glen Canyon Group in this area consists of the Wingate Sandstone, Kayenta Formation, and the Navajo Sandstone, in ascending order. West of the area, a fourth formation, the Moenave, is recognized.

\section{WINGATE SANDSTONE}

South of Laguna Creek the Wingate consists of two members: the Rock Point and the overlying Lukachukai. North of Laguna Creek, however, the Wingate consists only of the Lukachukai and the Rock Point is treated as the Church Rock Member of the Chinle (Witkind and Thaden, 1963, p. 32-34).

Lukachukai Member.-The Lukachukai Member consists of resistant, cliff-forming, thick-bedded, cross-stratified reddish-brown sandstone composed mostly of fine- to medium-grained quartz that contains scattered coarse grains throughout. Cross-stratification is principally medium to large scale and the trough type. The member is thick bedded at the base and becomes somewhat thinner bedded (beds 3-5 ft thick) in the upper third. Near Kayenta the basal unit of the Lukachukai is a 75-foot-thick bed of relatively soft parallel-bedded conglomeratic sandstone. Pebbles and coarse sand grains occur mostly near the base of this unit in thin stringers and sheets parallel to the bedding. Conglomeratic sandstone was not found in the Lukachukai Member at Marsh Pass. Where the Lukachukai is flat lying, it weathers into vertical blocky cliffs; where it dips steeply, it forms cuestas and hogbacks. 
The Lukachukai Member is 283 feet thick near Kayenta and 195 feet thick at Marsh Pass. G. O. Bachman (oral commun., 1957) reported that the Lukachukai is 204 feet thick at Betatakin National Monument, 12 miles west of Marsh Pass.

At most places south of Laguna Creek the Lukachukai-Rock Point contact appears to be comformable. Near Kayenta, conglomeratic sandstone in the lower part of the Lukachukai rests sharply on siltstone and sandstone of the Rock Point, but this sharp lithologic break was observed only in the Kayenta area; it probably is not of regional significance. According to Harshbarger, Repenning, and Irwin (1957, p. 9), the Lukachukai and Rock Point intertongue.

The Lukachukai is considered to be an eolian deposit of Late Triassic age (Harshbarger, Repenning, and Irwin, 1957, p. 11-12; Lewis, Irwin, and Wilson, 1961, p. 1440).

\section{KAYENTA FORMATION}

The Kayenta Formation is mostly very fine grained to mediumgrained sandstone interbedded with lesser amounts of clay shale. Generally, the sandstone beds are 2-4 feet thick. The sandstone and shale are generally grayish red or pale red. The formation contrasts markedly with the underlying Lukachukai Member of the Wingate Sandstone by being thinner bedded and by weathering to a bench. The Kayenta Formation is 134 feet thick in the Kayenta area and 200 feet thick at Marsh Pass.

According to Harshbarger, Repenning, and Irwin (1957, fig. 10), the Moenave Formation, which underlies the Kayenta and overlies the Wingate in nearby areas to the southwest, is 125 feet thick at Marsh Pass and pinches out between Marsh Pass and Kayenta. We could not distinguish the Moenave from the Kayenta in the area mapped, and strata called the Moenave by Harshbarger, Repenning, and Irwin (1957) are here included in the Kayenta.

The contact between the Kayenta Formation and the underlying Lukachukai Member of the Wingate reportedly is an erosional unconformity (Harshbarger, Repenning, and Irwin, 1957, p. 11). At Marsh Pass the contact is an irregular surface at the base of a purplish-gray sandstone containing small pebbles and sandstone fragments. At the top of the Lukachukai Member, this bed rests on a lenticular 10- to 12-foot-thick unit of soft mudstone and silty shale.

The Kayenta Formation is Late Triassic(?) in age according to Lewis, Irwin, and Wilson (1961, p. 1440).

\section{NAVAJO SANDSTONE}

The Navajo Sandstone is massive highly cross-stratified moderatereddish-orange to grayish-orange quartz sandstone which contains a 
few thin beds of lenticular gray cherty limestone or marl. The crossstratification is the high-angle trough type, and the individual cross strata are as much as 200 feet long. The sandstone is moderately well sorted; most of the grains are fine to very fine $(0.062-0.25 \mathrm{~mm})$. Individual quartz grains are spherical. The limestone beds range from less than 1 foot to about 3 feet in thickness and are generally less than 1 mile long. The Navajo crops out in steep cliffs and in irregularly rounded slopes marked at intervals by smooth conical hills. It is 740 feet thick at Kayenta and 705 feet thick at Marsh Pass.

The Navajo rests with a sharp contact upon the Kayenta Formation in the mapped area; however, Harshbarger, Repenning, and Irwin $(1957$, p. 22) noted that the lower part of the Navajo and upper part of the Kayenta intertongue nearby.

The Navajo Sandstone is considered by Lewis, Irwin, and Wilson (1961, p. 1439) to be Late Triassic (?) and Jurassic in age.

\section{JURASSIC ROCKS}

\section{SAN RAFAEL GROUP}

The San Rafael Group in the report area consists of (in ascending order) the Carmel Formation, Entrada Sandstone, and Summerville Formation. The three formations were mapped separately in the eastern half of the area of this report. In the western half the Carmel Formation can be recognized locally, but because of poor exposures and relatively uniform lithology, the Entrada and the Summerville were mapped as a single unit.

\section{CARMEL FORMATION}

The Carmel Formation is poorly exposed in the report area. It is composed principally of reddish-orange-brown sandy and silty shale and siltstone with thin interbeds of sandstone. The sandstone beds, particularly the better sorted ones, are predominantly white and weather to light gray. The sandstone is composed mainly of very fine grained to medium-grained quartz but also includes small amounts of pink chert, weathered feldspar, and dark minerals. The grains are subangular to well rounded; the well-rounded grains have frosted surfaces. The bedding is mostly parallel, but several thin sandstone beds and one 5-foot-thick sandstone bed at the top of the Carmel are cross-stratified. Current ripple marks were observed near the base of the formation on a bed of reddish-brown sandy siltstone.

The Carmel is 128 feet thick near the southwest corner of the area adjacent to the Kayenta-Tuba City road. It is about 130 feet thick in a water well drilled $11 / 2$ miles east of the southeast corner of the report area. R. B. O'Sullivan (oral commun., 1956) stated that the Carmel is 134 feet thick at Garnet Ridge and 76 feet thick at Red 
Point. These localities are a short distance north and east of the area discussed in this report.

The contact between the Carmel and the underlying Navajo Sandstone is covered nearly everywhere in the mapped area by alluvium, drifted sand, or landslide debris. At an outcrop near Kayenta and at another outcrop at the south end of Longhouse Valley, however, the contact is sharp. Baker, Dane, and Reeside $(1936$, p. 7) concluded that although the contact is distinct where observed, there is little evidence to indicate that it represents a significant depositional break. On the other hand, Harshbarger, Repenning, and Irwin (1957, p. 33) reported an erosional unconformity between the Carmel and the Navajo that might represent a considerable part of Middle Jurassic time.

The age of the Carmel is not definitely known, but currently accepted views place its age as Middle and Late Jurassic (Imlay, 1952, p. 963-964). The entire formation in the Navajo country may be of Late Jurassic age (Harshbarger, Repenning, and Irwin, 1957, p. 25). Stokes $(1954$, p. 37) stated that the age of the Carmel is late Early. and early Middle Jurassic. No fossils have been found in the Carmel in the Navajo country.

\section{ENTRADA SANDSTONE}

The Entrada Sandstone is nonresistant and is covered almost everywhere by surficial deposits of sand, alluvium, and landslide debris. The upper part of the formation is well exposed at scattered outcrops about 4 miles southeast of Kayenta. The lower part is mostly covered.

In the eastern part of the area, the Entrada can be divided into two units identified by Harshbarger, Repenning, and Irwin (1957, p. 3538 ) as the lower sandy member and the medial silty member of the Entrada; their upper sandy member is not present in the report area.

The lower part of the Entrada consists of very friable gray, lightreddish-orange, and light-tan massive cross-stratified very fine grained to medium-grained quartz sandtsone. The unit weathers to smooth rounded ledges. Cross-stratification is the medium- to large-scale trough type and suggests eolian deposition. The sand grains are subangular to well rounded and are characteristically frosted or pitted. The medium-sized grains $(0.25-0.50 \mathrm{~mm})$ are almost spherical. A size analysis of a sample of this sandstone showed 6 percent of the grains to be of medium size, 47 percent fine, 40 percent very fine, and 7 percent of silt size or smaller. The larger grains are concentrated in thin bands along the cross-stratification surfaces.

The upper part of the Entrada is friable to moderately indurated very fine grained clayey, silty sandstone and sandy siltstone that weather to smooth ledges. The rock is reddish orange and is regu- 
larly to irregularly bedded. The irregular bedding is due to mild folding which apparently occurred prior to consolidation of the sediments and is attributed to submarine slumping (Harshbarger, Repenning, and Irwin, 1957, p. 38). At a few places the sandstone beds are separated by thin clayey laminae. Locally, the member is deeply weathered along vertical joints and forms strangely shaped knobs known as "stone babies," "voodoos," or "pillow structures." These features are well displayed at Baby Rock Point, just northeast of the report area.

A complete section of the Entrada was not measured in the eastern part of the area because the lower part is poorly exposed. The upper part is 132 feet thick at Tselichii Point. Complete sections of the Entrada measured by R. B. O'Sullivan and associates (oral commun., 1956) are 160 feet thick at the north end of Red Point Mesa and 186 feet thick at Garnet Ridge. These sections are approximately 5 and 14 miles east and north of the report area. The Entrada is about 180 feet thick in a water well drilled about 1 mile east of the southeast corner of the map area. Thus, in the east half of the area, the entire Entrada is about 180 feet thick and its lower part is about 50 feet thick. In the Marsh Pass area to the west the thickness of the Entrada was not determined because of poorly exposed outcrops.

The Entrada-Carmel contact was not clearly observed anywhere in the report area. It reportedly is conformable and ranges from distinct to gradational (Baker, Dane, and Reeside, 1936, p. 7). The contact between the medial and lower members of the Entrada is exposed at Tselichii Point, where it is distinct and appears conformable.

The Entrada is early Late Jurassic in age (Imlay, 1952, pl. 1, and p. 961-963).

\section{SUMMERVILLE FORMATION}

The Summerville Formation is well exposed at several localities in the east half of the area, but equivalent rocks in the west half are covered almost everywhere.

Near Tselichii Point the Summerville consists of moderate-reddishbrown, light-brown, and light-brownish-gray moderately soft to friable cross-stratified very fine grained to medium-grained sandstone. The beds in the lower part of the unit range in thickness from 20 to 40 feet; in the upper part, from 3 to 10 feet. The formation weathers to smooth cliffs.

At Buried Hogan Point, a short distance north-northwest of Tselichii Point, the Summerville Formation consists of two sandstone units. The lower unit is banded reddish brown and light brown; the upper unit is cream colored to light brown and cross-stratified. East of the report area, along Tyende Wash, the Summerville consists of a lower 
sequence of parallel-bedded very fine grained to coarse-grained lightbrown to light-gray sandstone and thin interbeds of dark-reddishbrown shale. These beds are overlain by a thicker sequence of very light gray and white cross-stratified fine- to medium-grained sandstone. The upper light-colored sandstone unit is considered by some geologists to be a thin tongue of the Bluff Sandstone of the Four Corners area (L. C. Craig, written commun., 1962) and was treated as the "upper sandy member of the Summerville" by Harshbarger, Repenning, and Irwin (1957, p.43).

South of Kayenta in the scattered exposures on Black Mesa the Summerville consists of soft reddish-orange very fine grained silty sandstone that has poorly displayed cross-lamination. There, it is difficult to distinguish the Summerville from the underlying Entrada.

The thickness of the Summerville was not measured in the mapped area. R. B. O'Sullivan, however, measured a 171-foot-thick section approximately 5 miles southeast of the area.

\section{COW SPRINGS SANDSTONE}

The upper part of the Cow Springs Sandstone crops out in a rounded cliff in the southwestern part of the area, in Longhouse Valley, southwest of Marsh Pass. The base is covered by alluvium every where in Longhouse Valley and at Marsh Pass.

The Cow Springs consists of very light gray sandstone; locally, it is tinted shades of pale green and yellow. The sandstone is crossstratified on a large scale. It is composed mostly of fine-grained to very fine grained quartz but includes silt and clay. A size analysis of a sample from the Cow Springs collected in Marsh Pass shows the following textures: Fine $(0.125-0.25 \mathrm{~mm}), 23$ percent; very fine $(0.062-0.125 \mathrm{~mm}), 63$ percent; silt and clay (less than $0.062 \mathrm{~mm}), 14$ percent. Minerals other than quartz make up less than 1 percent of the total and are most abundant in the finest fraction. Most sand grains are subangular, but a few are angular.

The thickness of the Cow Springs in the report area ranges from a featheredge north of Marsh Pass to more than 75 feet at the south end of Longhouse Valley. At the north end of Longhouse Valley, the Cow Springs is 50 feet thick.

South of the report area the Cow Springs intertongues with underlying units of the San Rafael Group (Harshbarger, Repenning, and Irwin, 1957, p. 48-51) ; to the north it intertongues with the Salt Wash Member of the Morrison Formation and appears to pinch out north of Marsh Pass (pl.2).

\section{MORRISON FORMATION}

The Morrison Formation is divided, in ascending order, into the Salt Wash, Recapture, and Westwater Canyon Members. A younger 
unit, the Brushy Basin Member, is not present in the report area but may be present elsewhere along the northeast flank of Black Mesa (Harshbarger, Repenning, and Irwin, 1957, p. 55). Because of poorly exposed outcrops and the lithologic gradation between the Salt Wash and Recapture Members, these two members are shown on the map (pl. 1) as a single unit but are differentiated on the stratigraphic sections (pl.2).

Southeast of Kayenta the outcrop of the Morrison Formation is several miles wide and the formation is about 740 feet thick: Salt Wash Member, 160 feet; Recapture Member, 420 feet; and Westwater Canyon Member, 160 feet. The thicknesses were somewhat arbitrarily determined because the contacts between units are gradational. At the north end of Marsh Pass, the total thickness of the Morrison is 750 feet: Salt Wash, 195 feet; Recapture, 255 feet; and Westwater Canyon, 200 feet. At the south end of Longhouse Valley, the Morrison is about 330 feet thick and is represented mostly by the Recapture Member; the Salt Wash is absent, but sandstone 25-35 feet thick at the top of the formation may be assigned to the Westwater Canyon Member.

The Morrison Formation is assigned a Late Jurassic age (Imlay, 1952, p. 953).

Salt Wash Member.-The Salt Wash Member is predominantly light-gray to grayish-brown sandstone with lesser and varying amounts of clay shale, silty shale, and conglomeratic sandstone. Some sandstone beds are well sorted and fine grained or very fine grained; other beds are poorly sorted and very fine grained to pebbly. Beds range from thin to thick, and individual beds are lenticular and show different types of cross-stratification. The siltstone and shale are moderately reddish brown to greenish gray, and they tend to be most abundant in the upper part of the member. The sandstone ranges from friable to well cemented, and the beds are somewhat more resistant to erosion than the overlying and underlying units. The shale beds are soft and easily eroded. This combination produces a slabby ledge-forming unit which contrasts with the more massive smooth-weathering strata in the upper part of the underlying San Rafael Group.

At Marsh Pass the Salt Wash Member is noticeably more conglomeratic in the upper two-thirds than in the lower third. A soft yellowish- and greenish-gray fine-grained sandstone, 23 feet thick and resembling the Cow Springs, was noted 45 feet above the base of the Salt Wash.

The Salt Wash-Summerville contact is well exposed in most of the east half of the report area, and the contrasting weathering characteristics provide an easily recognizable horizon for mapping. Ledge- 
forming sandstone of the Salt Wash Member is at some places underlain by thin reddish-brown shale in the Summerville. At other places however sandstone of the Morrison is in direct and apparently conformable contact with sandstone of the Summerville. The Salt Wash appears to pinch out south of Marsh Pass in Longhouse Valley.

Recapture Member.-The Recapture Member is predominantly soft red shale which forms broad benches and gentle slopes. The member contains a variable amount of light-gray and white friable sandstone and a small amount of greenish-gray shale. The shale is mostly silty and sandy. Sandstone, in 1- to 10-foot-thick lenticular beds, is most abundant toward the top and bottom of the member. The sandstone is generally fine grained, although some beds contain granules and pebbles as much as three-quarters of an inch in diameter. The coarser material is commonly found along cross-stratification surfaces.

Westwater Canyon Member.-The Westwater Canyon Member is the uppermost member of the Morrison Formation in the report area. About 90 percent of the member is sandstone; the remainder is reddish-brown or greenish-gray sandy siltstone and shale. The sandstone is very light yellowish gray to cream colored; it is friable and generally weathers to smooth ledges. The beds are 5-20 feet thick, lenticular, and commonly cross-laminated. The sandstone is mostly fine grained but contains some lenses of conglomerate and poorly sorted sandstone. Despite the friability the member is well exposed in most places and forms steep cliffs.

\section{CRETACEOUS ROCKS}

\section{DAKOTA SANDSTONE}

The Dakota Sandstone, the oldest formation of Cretaceous age in the report area, crops out in an irregular band along the edge of a broad bench at the base of Black Mesa. Along the northwest side of Black Mesa, the Dakota forms a prominent cuesta. The lower part of the Dakota is excellently exposed throughout most of the mapped area; the upper part is less resistant to erosion, and at many places the top of the formation is covered. The Dakota Sandstone thickens irregularly westward from 82 feet near Chilchinbito to 200 feet in Longhouse Valley.

In general, the Dakota consists of a lower sandstone, a medial carbonaceous shale, and an upper sandstone. The lower sandstone ranges in thickness from about 40 feet near the south end of Longhouse Valley and at a point about 1 mile west of Chilchinbito to nearly 80 feet at Kayenta Point. It is cross-stratified and irregularly medium to thick bedded; locally it forms a single massive bed. The sandstone weathers yellowish brown, which contrasts with the lighter weather- 
ing color of the sandstone of the underlying Morrison. This unit varies considerably in texture, but generally it consists of poorly sorted medium-grained to very coarse grained sandstone containing discontinuous lenses of pebble conglomerate. The sandstone is composed principally of quartz but contains fresh and altered feldspar, mica, and chert. Clay balls compose part of the conglomeratic fraction. Contorted coal and carbonaceous shale streaks are present in many places and locally occur at the base of the sandstone. Channeling of underlying beds was noted at every locality examined, and the Dakota was deposited upon an irregular erosional surface cut in the Morrison (Harshbarger, Repenning, and Irwin, 1957, p. 57).

The shale unit of the Dakota ranges in thickness from about 36 feet near Chilchinbito to 73 feet near Lolomai Point. It consists dominantly of carbonaceous shale but contains very lenticular coal beds, ferruginous concretions, and thin irregular beds of light-gray fine- to medium-grained sandstone. Locally, as many as three coal beds may be present, each more than 2 feet thick. More commonly, only one or two beds of dirty coal less than 2 feet thick, or only carbonaceous shale and no coal, are present.

The upper sandstone unit of the Dakota is less than 15 feet thick at most places in the mapped area; locally it is absent. The sandstone is generally fine grained and varies from well cemented to very friable. Abundant remains of the oyster Gryphaea newberryi are present in many places near the top of this unit.

Plant fossils collected by G. A. Williams from the Dakota south of Marsh Pass were tentatively identified as Late Cretaceous in age (Repenning and Page, 1956, p. 262). Invertebrate fossils collected by R. B. O'Sullivan (oral commun., 1956) from beds within the Dakota Sandstone in the southwestern part of Black Mesa have also been tentatively identified as Late Cretaceous. Cobban and Reeside (1952, chart 10b) considered the entire Dakota sequence as Late Cretaceous, but Repenning and Page (1956, p. 262-263) pointed out that fossils are absent at the base of the Dakota in Black Mesa and that the Dakota in this area may be Early Cretaceous in age. The Dakota Sandstone is classified in the present report as Early and Late Cretaceous in age.

\section{MANCOS SHALE}

The Mancos Shale, which ranges in thickness from about 675 to 850 feet in the report area, forms a broad slope and a series of smooth benches around the north end of Black Mesa. It weathers to bands of light-and dark-gray and tan soil. The Mancos consists principally of clay shale and silty shale and contains lesser amounts of calcitecemented thin-bedded slabby very fine grained silty sandstone and 
siltstone. Selenite (gypsum) is common. Thin beds of bentonitic clay were noted by Williams (p. 118-121) ${ }^{1}$ in the lower part of the Mancos.

The contact of the Mancos and Dakota Formations is gradational. For purposes of mapping, the base of the Mancos is placed at the top of the highest sandstone bed that is more than 3 feet thick. Williams (p. 96) ${ }^{1}$ placed the basal contact of the Mancos below strata containing marine fossils, usually on top of a coal bed, which is a few feet stratigraphically lower than the contact we have chosen.

The Mancos Shale in the Black Mesa region is richly fossiliferous. From fossil collected south of Kayenta, Reeside and Baker (1929) concluded that approximately the lower fourth of the Mancos is of Graneros, and Greenhorn age, and that the upper part probably includes Carlile equivalents. Repenning and Page (1956, p. 266) stated: "In brief, the Mancos of *** [the Black Mesa] * * * area appears to include equivalents of most of the Greenhorn limestone and the Carlile shale of the Colorado Front Range, although oldest Greenhorn faunal zones and youngest Carlile zones have not been recognized."

\section{MESA VERDE GROUP}

The Mesaverde Group in the Black Mesa region was divided, in ascending order, into the Toreva Formation, Wepo Formation, and Yale Point Sandstone by Repenning and Page (1956, p. 271), and it was comprehensively discussed by them. These units are equivalent to the lower part of the Mesaverde Group in the southern part of the San Juan Basin in New Mexico (Beaumont, Dane, and Sears, 1956, fig. 3). With the possible exception of the uppermost part of the Yale Point Sandstone, the three formations are older than the typical Mesaverde Group of southeastern Colorado (Pike, 1947, p. 37).

\section{TOREVA FORMATION}

Repenning and Page (1956, p. 271-275) subdivided the Toreva Formation in the northern part of Black Mesa into a basal sandstone, a medial marine shale, and an upper sandstone. These three units are recognizable from Kayenta Point southeastward, but they are not readily recognized to the southwest; from Marsh Pass southward the shale unit is not present. The map scale and the narrow outcrop of the Toreva prevent differentiating these units on the geologic map (pl. 1), but the units are differentiated on the graphic sections (pl. 2).

The Toreva is well exposed on steep cliffs in the east half of the area, but it is not as well exposed in the west; it is easily accessible only from Marsh Pass southwestward. Near the south end of Marsh Pass, the

\footnotetext{
1 Williams, G. A., 1951, The coal deposits and Cretaceous stratigraphy of the western part of Black Mesa, Arizona: Tucson, Univ. Arizona unpub. Ph. D. thesis.
} 
Toreva is about 242 feet thick; southwest of Chilchinbito it is about 278 feet thick. The sandstone units are fine to medium grained except for locally abundant lenses of coarse-grained sandstone containing fragments of granite. This coarse material is most abundant in the upper part of the lower sandstone and in the upper sandstone. All the sandstone beds are moderately cross-stratified, and the crossstratification is generally of the low-angle wedge and planar types. The marine shale unit is a varied unit consisting of gray and tan silty and sandy shale and intercalated thin tan sandstone beds. Coal and carbonaceous shale were observed in the lower part of this unit in the vicinity of Chilchinbito; and a small amount of coal, carbonaceous shale, and siltstone occurs in thin beds within the lower part of the Toreva Formation near Kayenta Point and Marsh Pass.

The Toreva grades downward into the underlying Mancos Shale within a 10- to 50 -foot-thick interval in which sandstone is interbedded with shale. The base of the Toreva is placed where the sandstone predominates over shale.

\section{WEPO FORMATION}

The Wepo Formation is exposed in nearly vertical cliffs and steep slopes on the northward-and northeastward-facing escarpment of Black Mesa. It is exposed also in the deep canyons and the hills on top of the mesa and extending southward to the southern limit of the mapped area. The Wepo consists of lenticular sandstone, claystone, siltstone, shale, and coal beds. The sandstone weathers to gray and $\tan$ and is very fine grained to medium grained, friable to well indurated, and cross-stratified. At many places it forms lenses deposited in channels cut in the underlying strata. The claystone, siltstone, and shale beds generally contain much organic material and are characteristically dark brown or purplish brown. The coal beds range from thin streaks and lenses to beds as thick as 5 feet. Considerable amounts of bone coal and numerous siltstone and mudstone partings are present in most of the coal beds. The percentage of sandstone in the Wepo seems to be greatest at the northernmost end of Black Mesa near Kayenta Point. There the sandstone makes up about 85 percent of the formation; at other places it constitutes as little as 50 percent of the formation.

The Wepo Formation on the north and northeast face of Black Mesa is 130-185 feet thick. Presumably, the formation is somewhat thicker in the southern part of the area where it tongues with and replaces the overlying beds of the Yale Point Sandstone.

The Wepo Formation rests gradationally on the Toreva Formation. The gradational change probably represents a change from a marine 
near-shore depositional environment to a lagoonal and fluviatile environment.

The lower beds of the Wepo are late Carlile in age, and the upper beds in the southern part of Black Mesa are early Niobrara in age (Repenning and Page, 1956, p. 279).

\section{YALE POINT SANDSTONE}

The Yale Point Sandstone forms the top of Black Mesa at many places. This formation is thickest on the northeastern part of the mesa, thins southwestward, and pinches out in the Wepo Formation along the northwest-trending line in the southwestern part of the report area. The Yale Point is 244 feet thick at Lolomai Point, 260 feet thick west of Kayenta Point, 393 feet thick about $61 / 2$ miles northwest of Chilchinbito, and approximately 250 feet thick 2 miles southwest of Chilchinbito.

The Yale Point consists mostly of fine- to medium-grained subangular to subrounded quartz sandstone that contains some feldspar. Some of the sandstone is cross-stratified, and lenses of coarse sandstone are common along the planes of cross-stratification. At many places the lower 150-200 feet of the formation forms a single massive bed; the upper part has beds generally 10-40 feet thick separated by thin zones of shale and siltstone that locally contain a few thin lenses of coal.

\section{IGNEOUS ROCKS}

Three volcanic necks and a group of igneous dikes occur along the north edge of the area and in the southeastern part. These igneous bodies are of Tertiary age and belong to two main centers of igneous activity: the Monument Valley and Hopi Buttes volcanic fields. Gregory (1917, p. 83-108) and Williams (1936) discussed the petrology and mode of emplacement of these and other igneous rocks in this region.

\section{BLACK ROCK}

A small volcanic neck, locally known as Black Rock, rises above outcrops of the Navajo Sandstone about 2 miles east of Kayenta. Gregory $(1917$, p. 101) termed this feature "Tyende dikes" but described it as a volcanic neck composed of two 300 -foot-high dikelike masses and an intervening mass of agglomerate or breccia. He noted the presence of abundant iron, bronze-colored biotite, augite, and olivine in a groundmass of alkalic feldspar, and classified the rock as an "augite minette." The mass is intruded by what appears to be a vein of minette. Williams (1936, p. 133) noted that the border of sandstone inclusions in the minette is altered to quartzite. 


\section{CHURCH ROCK}

Church Rock rises about 300 feet above the valley alluvium some 8 miles east of Kayenta. The igneous rock that makes up the outcrop weathers to moderate greenish brown; unweathered rock is light gray and greenish gray. According to Gregory (1917, p. 101), the Church Rock mass consists of groups of almost parallel dikes separated and surrounded by a breccia or agglomerate of sandstone and igneous fragments of various sizes in quantities greatly exceeding the amount of unmodified igneous rock found in the dikes. Williams $(1936, \mathrm{p} .133)$ pointed out that blocks of sandstone of Jurassic age as much as 100 yards across are incorporated in the mass. He classed the igneous material as minette.

A dike trending southeast from Church Rock is exceptional in that it contains a great amount of sedimentary rock. Away from Church Rock the thickness of the dike gradually decreases from 20 to 5 feet. The dike rock is greenish gray and contains numerous flakes of mica.

\section{PORRAS DIKES}

About 5 miles east of Kayenta, a group of north-trending lamprophyric (Witkind and Thaden, 1963, p. 54) dikes intrude the Navajo Sandstone. These are the southernmost dikes of a complex dike system named the Porras dikes by Gregory (1917, p. 153).

\section{CHILCHINBITO ROCK}

Chilchinbito Rock, some 3 miles north and slightly west of Chilchinbito trading post, is a volcanic neck that rises nearly 100 feet above the surrounding Morrison sandstone. Dikes extend outward from the neck in opposite directions and trend N. $37^{\circ} \mathrm{W}$. The northwest dike can be traced for half a mile and is about 5 feet thick. The southeast dike can be traced intermittently for nearly 2 miles and is about 10 feet thick. The neck is elongated in the direction of the dikes and tapers into them.

The igneous rock in both the neck and the dikes is a micaceous minette and agglomerate and is crumbly on weathered surfaces (Gregory, 1917, p. 106; Williams, 1936, p. 133). Fragments of sandstone and shale, chert pebbles, and granite and granitoid gneiss were observed as inclusions in the agglomerate.

Bedded pyroclastic debris including lapilli bombs 1 foot long is present at the periphery of the neck. The bedded rocks dip steeply toward the nonbedded core. Williams $(1936$, p. 132) believed that the stratified pyroclastic rocks are ejectamenta that fell into the volcanic conduit following explosive action. 


\section{STRUCTURAL FEATURES}

The larger part of the area considered in this report lies on the north margin of the Black Mesa basin, a large structural depression in the southern part of the Colorado Plateau province. The northern and eastern parts of the report area lie within the Piute folds region, the Oljeto sag, the Monument upwarp, and the Tyende saddle structural divisions made by Kelley (1955), as shown in figure 1.

Structure contours (interval: $100 \mathrm{ft}$ ) of the top of the Navajo Sandstone in the report area are shown on plate 1.

\section{BLACK MESA BASIN}

The Black Mesa basin is a major structural depression in northern Arizona. The northern part of the basin extends into the southwestern part of the mapped area, coinciding with Black Mesa. The Mesaverde Group of Cretaceous age forms most of the surface rock in the part of the basin in the report area. Sedimentary rocks cropping out in the northern part of the basin dip generally southward at low angles toward the axis of the basin, which lies more than 20 miles south of the mapped area.

\section{ORGAN ROCK MONOCLINE AND NEARBY FOLDS}

The largest fold in the report area is the sinuous south-trending Organ Rock monocline, which brings the Navajo Sandstone of Triassic(?) and Jurassic age and older rocks to the surface in the northwestern part of the area. The Organ Rock monocline can be traced from a point north of the San Juan River in southern Utah southward for about 90 miles to a point about 30 miles beyond the report area. Jurassic rocks exposed in the zone of steepest folding dip as much as $32^{\circ}$ SE. near Marsh Pass. At the crest of the monocline, the dips flatten; north of the Tsegi trading post they are reversed to form the northeast-trending Organ Rock anticline. The Petrified Forest Member of the Chinle Formation is exposed at the crest of a small dome on the anticlinal axis 5 miles north of the Tsegi trading post.

Near Marsh Pass the Organ Rock monocline turns westward and is interrupted by two plunging synclines: the Tsegi syncline, which plunges southward, and the Longhouse embayment, which plunges southeastward (pl.1).

\section{COMB MONOCLINE AND OLJETO SYNCLINE}

A small part of a large structural feature known as the Comb monocline is present along the north edge of the report area near Kayenta. This monocline is a sharp flexure that can be traced through 
Arizona and Utah for about 80 miles. In the report area the maximum dip recorded on the Comb monocline was about $20^{\circ} \mathrm{S}$, measured in the Navajo Sandstone, which is the surface formation generally involved in the steepest folding. The Comb monocline is separated from the Organ Rock monocline to the west by the Oljeto syncline, which plunges southward and dies out at the north margin of the Black Mesa basin. At the margin of the basin, two shallow anticlines and a syncline border the axis of the Oljeto syncline to the southwest.

\section{KAYENTA ANTICLINE AND ADJACENT FOLDS}

The Kayenta anticline is a shallow fold that extends from Comb monocline southwestward for about 10 miles to the north edge of the Black Mesa basin. Rocks of the San Rafael Group are exposed at most places along the axis. A small anticlinal nose projects southward from the main fold near its north end. The two anticlines are almost symmetrical; a maximum dip of about $3^{\circ}$ was measured on the southwest flank of the south nose. A shallow syncline in the San Rafael Group and Morrison Formation parallels the Kayenta anticline on the northwest.

\section{BABY ROCKS SYNCLINE}

Baby Rocks syncline, a shallow synclinal trough that has been referred to as the Tyende Creek syncline (Kelley, 1955, fig. 2), can be traced from the central part of the mapped area northeastward for more than 40 miles beyond the mapped area. The axial trace closely parallels the strike of Comb monocline beyond the limit of the report area. The syncline is symmetrical, and the axis is slightly undulatory. At the southwest end the fold plunges gently southwest into the Black Mesa basin. The Morrison Formation is the unit exposed along most of the synclinal axis.

\section{BURIED HOGAN DOME AND RED POINT MESA ANTICLINE}

The Entrada Sandstone in the east-central part of the area is folded to form a nearly circular dome, here called the Buried Hogan dome. The dome appears to lie at the west end of a broad shallow northeasttrending anticline called the Red Point Mesa anticline. The Buried Hogan dome is in belt of igneous intrusives and may have been formed by an intrusive at depth. The maximum dip of rocks on the flanks of this dome is less than $3^{\circ}$, and closure seems to be less than 100 feet.

\section{ROUGH ROCK ANTICLINE}

The northwest-trending Rough Rock anticline is a shallow nearly symmetrical fold which extends about 10 miles into the southeastern part of the area. Sandstone in the Salt Wash Member of the Mor- 
rison Formation is the oldest rock exposed on the anticlinal crest in the mapped area. The fold dies out to the north against the flank of the Red Point Mesa anticline and is separated from it by the Tyende Creek syncline.

\section{CHILCHINBITO TERRACE}

The Chilchinbito terrace is a sector of relatively flat dips between the Rough Rock anticline on the east and Black Mesa basin on the west. Within this sector are several small, very shallow anticlinal and synclinal folds that trend generally westward. The Morrison Formation and younger rocks are exposed on Chilchinbito terrace.

\section{AGE OF FOLDING}

No field evidence was found to verify any depositional thinning of the rocks exposed in the structural features of this area, nor, according to I. J. Witkind (oral commun., 1964), in the area immediately to the north. This indicates a probable post-Cretaceous age for the formation of these features.

\section{OIL AND GAS POSSIBILITIES}

No wells had been drilled for oil and gas in the Kayenta or Chilchinbito quadrangles as of January 1,1964 . In adjacent areas, however, wells had been drilled into or through rocks of Paleozoic age; 13 of these wells are described in table 1, and 4 other wells, on plate 3. Data on the four dry holes (pl. 3) suggest that the report area is underlain by Paleozoic rocks which probably are more than 4,000 feet thick.

Rocks of every Paleozoic and Mesozoic system except the Silurian and Ordovician are probably present in the subsurface in the report area. The older Paleozoic formations were deposited in marine environments and are composed principally of carbonate rocks. Subsurface unconformities are present between Cambrian and Devonian rocks and between Mississippian and Pennsylvanian rocks in nearby areas. A possible unconformity between the Devonian and Mississippian systems is only inferred from the strong erosion that can be seen far to the west in Grand Canyon. Structural deformation possibly occurred prior to or during the periods of erosion or nondeposition. Clastic sediments are more abundant in the younger Paleozoic rocks, and they constitute most of the Permian rocks.

The oil- and gas-producing potential of rocks of pre-Pennsylvanian age is relatively unknown when compared with that of rocks of Pennsylvanian and post-Pennsylvanian age. Brown and Lauth (1957, p. 79) mentioned shows of oil and gas in rocks of Cambrian age in 
holes drilled in northwestern Arizona. These authors suggested that the Cambrian sequence holds promise in that area. Spragg (1952, p. 104) stated that according to available information, mechanical difficulties prevented the English 1, (sec. 22, T. 43 S., R. 22 E.) at Boundary Butte field in southeastern Utah, from being completed as a successful oil well. He reported oil and gas saturation in dolomite and anhydrite in the middle unit of the Pennsylvanian System and in dolomite of Devonian age in this same well. Following completion of the English 1, additional wells were drilled in the immediate and adjacent areas by other companies (Sheffer, 1958). These wells produced oil from the Shinarump Member of the Chinle and oil and gas from the Paradox Member of the Hermosa Formation.

TABLE 1.-Wells drilled in areas adjacent to the Kayenta and Chilchinbito quadrangles

\begin{tabular}{|c|c|c|c|c|c|c|c|c|c|}
\hline \multirow{2}{*}{ Well } & \multirow{2}{*}{$\begin{array}{l}\text { Structural } \\
\text { feature }\end{array}$} & \multicolumn{3}{|c|}{ Location } & \multirow{2}{*}{$\begin{array}{l}\text { Operator, } \\
\text { well number, } \\
\text { lease }\end{array}$} & \multirow{2}{*}{$\begin{array}{c}\text { Year } \\
\text { drilled }\end{array}$} & \multirow{2}{*}{$\begin{array}{l}\text { Producing } \\
\text { rocks }\end{array}$} & \multirow{2}{*}{$\begin{array}{l}\text { Total } \\
\text { depth } \\
\text { (feet) }\end{array}$} & \multirow{2}{*}{$\begin{array}{l}\text { Age of rocks } \\
\text { at total } \\
\text { depth }\end{array}$} \\
\hline & & Sec. & $\mathbf{T}$ & $\begin{array}{l}\mathrm{R} . \\
\mathrm{E} .\end{array}$ & & & & & \\
\hline
\end{tabular}

San Juan County, Utah

\begin{tabular}{|c|c|c|c|c|c|c|c|c|c|}
\hline $1 \ldots$ & $\begin{array}{l}\text { Unnamed } \\
\text { (west of } \\
\text { Chinle Wash). }\end{array}$ & 19 & $43 \mathrm{~S}$. & 21 & Texas Co. 1-AE .... & 1962 & $\begin{array}{l}\text { Mississip- } \\
\text { pian and } \\
\text { Pennsyl- } \\
\text { vanian. }\end{array}$ & 6,218 & Devonian. \\
\hline
\end{tabular}

Apache County, Ariz.

\begin{tabular}{|c|c|c|c|c|c|c|c|c|c|}
\hline $2 \ldots$ & $\begin{array}{l}\text { Unnamed } \\
\text { (northwest of } \\
\text { Walker } \\
\text { Creek) }\end{array}$ & 16 & $41 \mathrm{~N}$. & 25 & $\begin{array}{l}\text { Texas Co. } 1 \text { Navajo } \\
\text { AG. }\end{array}$ & 1963 & Devonian. - & 6,615 & $\begin{array}{l}\text { Pre- } \\
\text { cambrian. }\end{array}$ \\
\hline & $\begin{array}{l}\text { Walker Creek } \\
\text { anticline. }\end{array}$ & 30 & $40 \mathrm{~N}$. & 26 & $\begin{array}{l}\text { Bonanza Oil Corp. } \\
1 \text { Navajo. }\end{array}$ & 1961 & & 6,515 & Do. \\
\hline $5^{1} \ldots$ & _ & 11 & $40 \mathrm{~N}$. & 25 & $\begin{array}{l}\text { Pan Ainerican Pet. } \\
1 \text { Tohlacow- } \\
\text { Navajo. } \\
\text { Gulf } 1 \text { Walker Creek- }\end{array}$ & 1959 & & 6,598 & Devonian. \\
\hline $61 \ldots$ & ....do. & 20 & $40 \mathrm{~N}$. & 26 & $\begin{array}{l}\text { Navajo. } \\
\text { Texas Pacific Coal } \\
\text { and Oil Co. }\end{array}$ & 1959 & & 6,424 & Cambrian. \\
\hline $71 \ldots$ & $\begin{array}{l}\text { Walker Creek } \\
\text { anticline(?). }\end{array}$ & 23 & $41 \mathrm{~N}$. & 26 & $\begin{array}{l}\text { E. B. LaRue, Jr. } \\
1 \text { Dinne. }\end{array}$ & 1961 & & 6,332 & $\begin{array}{l}\text { Mississip- } \\
\text { pian. }\end{array}$ \\
\hline & $\begin{array}{l}\text { Unnamed } \\
\text { (west of Dry } \\
\text { Mesa anti- } \\
\text { cline). }\end{array}$ & 6 & $40 \mathrm{~N}$. & 28 & $\begin{array}{l}\text { Pan American } 1 \\
\text { Navajo Tribal } \\
\text { F-1. }\end{array}$ & 1962 & $\begin{array}{l}\text { Pennsyl- } \\
\text { vanian. }\end{array}$ & 7,359 & Devonian. \\
\hline & Dry Mesa & 2 & $40 \mathrm{~N}$. & 28 & Texas Pacific C\&O & 1960 & Mississip- & 5,411 & $\begin{array}{l}\text { Mississip- } \\
\text { pian. }\end{array}$ \\
\hline $10^{1}$ & do do & 11 & $40 \mathrm{~N}$ & 28 & Texas Pacific C\&O & 1960 & - non & 5. 799 & Do. \\
\hline $11 \ldots$ & $\ldots$ do & 12 & $40 \mathrm{~N}$. & 28 & $\begin{array}{l}\text { Texas Pacific C\&O } \\
2 \text { Navajo. }\end{array}$ & 1960 & $\begin{array}{l}\text { Mississip. } \\
\text { pian. }\end{array}$ & 5,771 & $\begin{array}{l}\text { Pre- } \\
\text { cambrian. }\end{array}$ \\
\hline $12 \ldots$ & $\begin{array}{l}\text { Dry Mesa anti- } \\
\text { cline(?). }\end{array}$ & 7 & $40 \mathrm{~N}$. & 29 & Atlantic 1 Navajo 7 . & 1961 & .....do_.... & 5.792 & Do. \\
\hline $13^{t}=$ & $\begin{array}{l}\text { Dry Mesa } \\
\text { anticline. }\end{array}$ & 1 & $40 \mathrm{~N}$ & 28 & $\begin{array}{l}\text { Pure Oil Co. } 5 \\
\text { Navajo } 138 .\end{array}$ & 1962 & $-2-2 .-2$. & 5,640 & $\begin{array}{l}\text { Mississip- } \\
\text { pian. }\end{array}$ \\
\hline
\end{tabular}

1 Dry and abandoned. 
West and slightly south of the Ohio 1 (pl. 3), oil was discovered in The Texas Co. 1-AE. Initial production was from Mississippian rocks, but the well was later plugged back and is now producing from the Pennsylvanian. Farther west and south The Texas Co. 1 Navajo AG is producing oil from Devonian rocks. Approximately 6-10 miles southeast, five wells have been drilled by different companies on what is defined as the Walker Creek anticline, but none of the wells has been productive. Two of the five tests bottomed in Precambrian. From 8 to 14 miles east of the Walker Creek wells, five more wells have been drilled in or near the Dry Mesa field. Two of these wells were nonproductive; however, the other three produce from Mississippian rocks. The Pan American-Navajo Tribal F-1, 4 miles west of the Dry Mesa field, produces oil from Pennsylvanian rocks. Brown and Lauth $(1957$, p. 79$)$ reported oil in Devonian limestone and dolomite that crop out along the Mogollon Rim, south of the Navajo country.

The most prolific oil- and gas-producing Paleozoic unit in the Four Corners region is the Hermosa Formation of Pennsylvanian age. The most productive zone in that formation is the Paradox Member, but in northeastern Arizona significant discoveries have been made below the Paradox Member. Though the Paradox Member is absent in the report area, the Hermosa Formation is present. It seems to become sandier to the southwest, as indicated on plate 3. Brown and Lauth (1957, p. 83) and Huddle and Dobrovolny (1945) reported shows of oil and gas from the Hermosa (Naco) Formation in the vicinity of Holbrook, south of the report area. In the Mexican Hat oil field in San Juan County, Utah, shallow production was obtained in small quantities from fine sandstone in the Rico Formation. The Supai Formation, partly equivalent to the Rico Formation, reportedly contains oil in the Holbrook area and might have been a producer with proper treatment (Brown and Lauth, 1957, p. 83).

On the basis of thickness of the Paleozoic strata underlying the Kayenta and Chilchinbito quadrangles and the presence of oil and gas in varying amounts in several Paleozoic formations nearby, eventual oil and gas production may reasonably be expected from somewhere in the report area.

\section{COAL}

Coal of possible economic importance occurs in the Dakota Sandstone and in the Wepo Formation, both of Cretaceous age. Some coal also occurs in thin beds and stringers in the Toreva Formation.

Although coal in the Dakota is economically valuable in the southern part of Black Mesa, it is too thin and impure where examined to 
be considered economically valuable. The coal occurs mainly in the middle, shale unit. The thickest bed observed, near the south end of Longhouse Valley, is nearly 5 feet thick; but it contains several partings, and the coal is dirty (locality C-3, pl. 1, fig. 3). Thinner beds were measured at two nearby localities, as shown on plate 1 and in figure 3.

Coal crops out in the upper part of the Wepo Formation along the steep north- and northeast-facing Black Mesa escarpment, in the walls of the many canyons cut through the Yale Point Sandstone into the Wepo Formation on top of Black Mesa, and in hilly areas in the southern part of the mapped area. The coal has burned nearly everywhere along its outcrop to form red slag or clinker.

Two coal mines, the Kayenta No. 1 and No. 2 (Maloney mine) (pl.1), were active before 1950 and 1952, respectively (Kiersch, 1955, p. 61), but were closed when we visited them in 1956. The coal from Kayenta No. 2 reportedly is high-volatile $\mathrm{C}$ bituminous (Kiersch, 1955, p. 61), which is relatively high rank for Cretaceous coal at Black Mesa. The principal bed in the Kayenta No. 1 coal mine reportedly is 12 feet thick (Kiersch, 1955, p. 61) but thins locally to 10 feet. A section measured at the portal of Kayenta No. 2 by G. H. Dixon and J. F. Fallis (section C-4, fig. 3) indicates that the bed is 11.6 feet thick, but only the lower 7.9 feet is sufficiently clean to be of value. Figure 3 and plate 1 show coal beds at 10 localities in and near the Kayenta mines.

Except for the coal in the Wepo at the Kayenta No. 1 and No. 2 mines, no economically valuable coal beds have been found in the Wepo or Toreva Formations in the report area. Coal of economic value may be present, however, in these formations elsewhere in Black Mesa. 


\section{DAKOTA SANDSTONE}

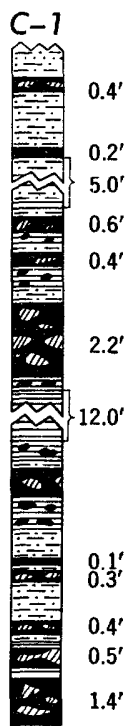

$95 \mathrm{ft}$ above base
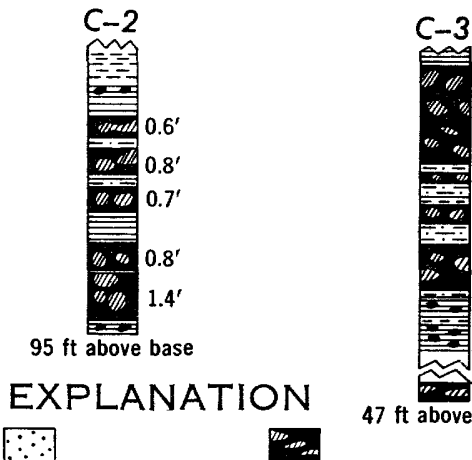

Sandstone

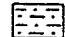

Siltstone and mudstone

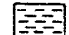

Shale and claystone

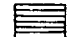

Carbonaceous shale

Unit not measured in detail
Coaly carbonaceous shale
$\begin{gathered}\text { Location of coal section } \\ \text { on geologic map }\end{gathered}$

WEPO FORMATION
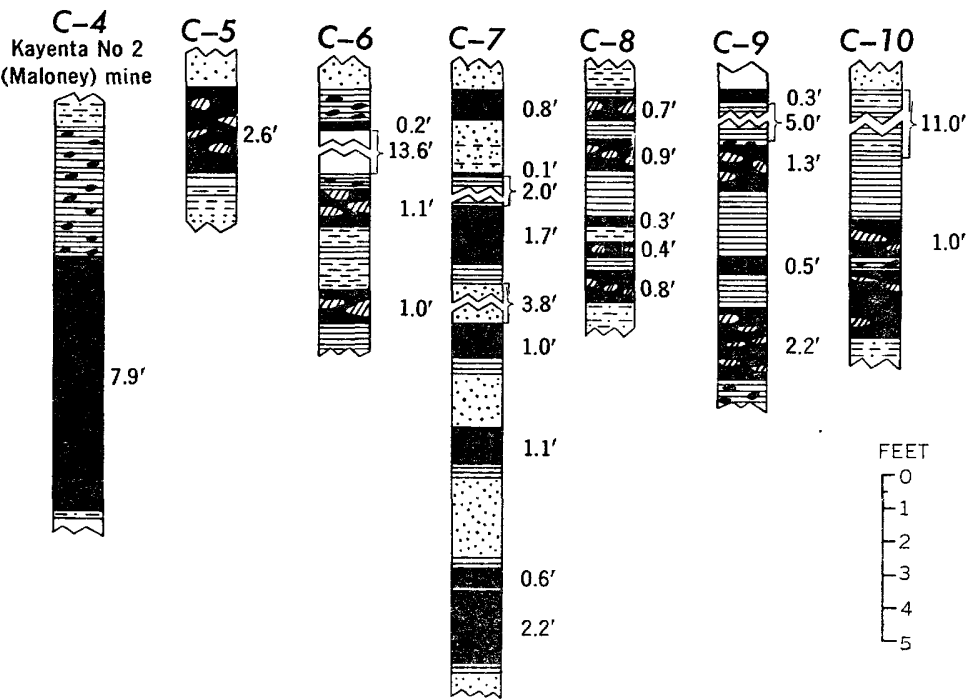

Frgure 3.-Coal beds in the Dakota Sandstone and the Wepo Formation. 


\section{SELECTED REFERENCES}

Averitt, Paul, Detterman, J. S., Harshbarger, J. W., Repenning, C. A., and Wilson, R. F., 1955, Revisions in correlation and nomenclature of Triassic and Jurassic formations in southwestern Utah and northern Arizona: Am. Assoc. Petroleum Geologists Bull., v. 39, no. 12, p. 2515-2524.

Baker, A. A., 1936, Geology of the Monument Valley-Navajo Mountain region, San Juan County, Utah : U.S. Geol. Survey Bull. 865, 106 p.

Baker, A. A., Dane, C. H., and McKnight, E. T., 1954, Preliminary map showing geologic structure of parts of Grand and San Juan Counties, Utah : U.S. Geol. Survey Oil and Gas Inv. Map OM-169.

Baker, A. A., Dane, C. H., and Reeside, J. B., Jr., 1936, Correlation of the Jurassic formations of parts of Utah, Arizona, New Mexico, and Colorado: U.S. Geol. Survey Prof. Paper 183, 66 p.

1947, Revised correlation of Jurassic formations of parts of Utah, Arizona, New Mexico, and Colorado: Am. Assoc. Petroleum Geologists Bull., v. 31, no. 9, p. 1664-1668.

Beaumont, E. C., Dane, C. H., and Sears, J. D., 1956, Revised nomenclature of the Mesaverde group in San Juan Basin, New Mexico: Am. Assoc. Petroleum Geologists Bull., v. 40, no. 9, p. 2149-2162.

Borden, J. L., 1952, Paradox member of the Hermosa formation [N. Mex.-Colo.], in Four Cormers Geol. Soc. symposium 1st, Four Corners region, 1952: p. 27-35.

Bradish, B. B., 1952, Geology of the Monument upwarp [Utah], in Four Corners Geol. Soc. symposium 1st, Four Corners region, 1952: p. 47-59.

Brown, S. C., and Lauth, R. E., 1957, Oil and gas potentialities of northern Arizona, in Four Corners Geol. Soc. 2d Field Conf. 1957: p. 77-84.

Cobban, W. A., and Reeside, J. B., Jr., 1952, Correlation of the Cretaceous formations of the Western Interior of the United States: Geol. Soc. America Bull., จ. 63, no. 10, p. 1011-1044.

Craig, L. C., and others, 1955, Stratigraphy of the Morrison and related formations, Colorado Plateau region, a preliminary report: U.S. Geol. Survey Bull. 1009-E, p. 125-168.

Gilluly, James, and Reeside, J. B., Jr., 1928, Sedimentary rocks of the San Rafael Swell and some adjacent areas in eastern Utah: U.S. Geol. Survey Prof. Paper 150-D, p. 61-110.

Gregory, H. E., 1917, Geology of the Navajo country ; a reconnaissance of parts of Arizona, New Mexico, and Utah: U.S. Geol. Survey Prof. Paper 93, 161 p.

Harshbarger, J. W., Repenning, C. A., and Irwin, J. H., 1957, Stratigraphy of the uppermost Triassic and the Jurassic rocks of the Navajo country [Colorado Plateau ] : U.S. Geol. Survey Prof. Paper 291, 74 p.

Harshbarger, J. W., Repenning, O. A., and Jackson, R. L., 1951, Jurassic stratigraphy of the Navajo country, in New Mexico Geol. Soc. Guidebook $2 d$ Field Conf., south and west sides of the San Juan Basin, New Mexico, 1951: p. 95-99.

Herman, George, and Barkell, C. A., 1957, Pennsylvanian stratigraphy and productive zones, Paradox Salt basin [Colorado Plateau] : Am. Assoc. Petroleum Geologists Bull., v. 41, no. 5, p. 861-881.

Huddle, J. W., and Dobrovolny, Emest, 1945, Late Paleozoic stratigraphy of central and northeastern Arizona : U.S. Geol. Survey Oil and Gas Inv. Prelim. Chart 10.

Imlay, R. W., 1952, Correlation of the Jurassic formations of North America, exclusive of Canada: Geol. Soc. America Bull., v. 63, no. 9, p. 954-992. 
Irwin, J. H., Repenning, C. A., and Stevens, P. R., 1955, Preliminary geologic map of the Agathla Peak 3 quadrangle, Arizona (1952), in Harshbarger, J. W., and others, Geologic maps of 28 quadrangles in west-central quarter of Navajo country (including 4 quadrangles prepared by Fuels Branch): U.S. Geol. Survey open-file report.

Kelley, V. C., 1955, Regional tectonics of the Colorado Plateau and relationship to the origin and distribution of uranium: New Mexico Univ. Pub. Geology, no. $5,120 \mathrm{p}$.

Kiersch, G. A., 1955, Metalliferous minerals and mineral fuels-geology, evaluation, and uses, and a section on the general geology, v. 1 of Mineral resources, Navajo-Hopi Indian Reservations, Arizona-Utah: Tucson, Arizona Univ. Press, 75 p. [1956].

Lewis, G. E., Irwin, J. H., and Wilson, R. F., 1961, Age of the Glen Canyon Group (Triassic and Jurassic) on the Colorado Plateau: Geol. Soc. America Bull., จ. 72, no. 9, p. 1437-1440.

O'Sullivan, R. B., and Beaumont, E. C., 1957, Preliminary geologic map of western San Juan Basin, San Juan and McKinley Counties, New Mexico: U.S. Geol. Survey Oil and Gas Inv. Map OM-190.

Pike, W. S., Jr., 1947, Intertonguing marine and nonmarine Upper Cretaceous deposits of New Mexico, Arizona, and southwestern Colorado: Geol. Soc. America Mem. 24, $103 \mathrm{p}$.

Reeside, J. B., Jr., and Baker, A. A., 1929, The Cretaceous section in Black Mesa, northern Arizona: Washington Acad. Sci. Jour., v. 19, no. 2, p. 30-37.

Repenning, C. A., and Irwin, J. H., 1955, Preliminary geologic map of the Agathla Peak 4 quadrange, Arizona (1952), in Harshbarger, J. W., and others, Geologic maps of 28 quadrangles in west-central quarter of Navajo country (including 4 quadrangles prepared by Fuels Branch): U.S. Geol. Survey open-file report.

Repenning, C. A., and Page, H. G., 1956, Late Cretaceous stratigraphy of Black Mesa, Navajo and Hopi Indian Reservations, Arizona: Am. Assoc. Petroleum Geologists Bull., v. 40, no. 2, p. 255-294.

Sears, J. D., 1956, Geology of Comb Ridge and vicinity north of San Juan River, San Juan County, Utah: U.S. Geol. Survey Bull. 1021-E, p. 167-207.

Sheffer, B. D., 1958, Boundary Butte area, San Juan and Apache Counties, Utah and Arizona, in Intermountain Assoc. Petroleum Geologists Guidebook 9th Ann. Field Conf. 1958: p. 262-267.

Spragg, John, 1952, Boundary Butte anticline, San Juan County, Utah, in Four Corners Geol. Soc. symposium 1st, Four Corners region, 1952: p. 104-105.

Stewart, J. H., 1957, Proposed nomenclature of part of Upper Triassic strata in southeastern Utah: Am. Assoc. Petroleum Geologists Bull., v. 41, no. 3, p. $441-465$.

Stokes, W. L., and Holmes, C. N., 1954, Jurassic rocks of south-central Utah, in Intermountain Assoc. Petroleum Geologists Guidebook 5th Ann. Field Conf., portions central and south-central Utah, $1954:$ p. 34-41.

Strobell, J. D., Jr., 1956, Geology of the Carrizo Mountains area in northeastern Arizona and northwestern New Mexico: U.S. Geol. Survey Oil and Gas Inv. Map OM-160.

Wanek, A. A., and Stephens, J. G., 1953, Reconnaissance geologic map of the Kaibito and Moenkopi Plateaus and parts of the Painted Desert, Coconico County, Arizona: U.S. Geol. Survey Oil and Gas Inv. Map OM-145.

Wengerd, S. A., 1951, Reef limestones of Hermosa formation, San Juan Canyon, Utah: Am. Assoc. Petroleum Geologists Bull., v. 35, no. 5, p. 1038-1051.

- 1955, Geology of the Mexican Hat oil field, San Juan County, Utah, in Four Corners Geol. Soc. [Guidebook] 1st Field Conf. : p. 150-163. 
Williams, Howel, 1936, Pliocene volcanoes of the Navajo-Hopi country: Geol. Soc. America Bull., v. 47, no. 1, p. 111-172.

Witkind, I. J., and Thaden, R. E., 1963, Geology and uranium-vanadium deposits of the Monument Valley area, Apache and Navajo Counties, Arizona : U.S. Geol. Survey Bull. 1108, 171 p.

Witkind, I. J., and others, 1956a, Preliminary geologic map of the Dinnehotso NW quadrangle, Arizona-Utah: U.S. Geol. Survey Mineral Inv. Field Studies Map MF-92 [1957].

-1956b, Preliminary geologic map of the Dinnehotso NE quadrangle, Arizona-Utah: U.S. Geol. Survey Mineral Inv. Field Studies Map MF-93 [1957].

1956c, Preliminary geologic map of the Dinnehotso SE quadrangle, Arizona: U.S. Geol. Survey Mineral Inv. Field Studies Map MF-94 [1957].

1956d, Preliminary map of the Dinnehotso SW quadrangle, Arizona : U.S. Geol. Survey Mineral Inv. Field Studies Map MF-95 [1957].

1957a, Preliminary geologic map of the Boot Mesa NW quadrangle, Arizona-Utah: U.S. Geol. Survey Mineral Inv. Field Studies Map MF-84.

1957b, Preliminary geologic map of the Boot Mesa NE quadrangle, ArizonaUtah: U.S. Geol. Survey Mineral Inv. Field Studies Map MF-85.

1957 c, Preliminary geologic map of the Boot Mesa SE quadrangle, Arizona: U.S. Geol. Survey Mineral Inv. Field Studies Map MF-86.

1957d, Preliminary geologic map of the Boot Mesa SW quadrangle, Arizona: U.S. Geol. Survey Mineral Inv. Field Studies Map MF-87.

1957e, Preliminary geologic map of the Agathla Peak NW quadrangle, Arizona-Utah: U.S. Geol. Survey Mineral Inv. Field Studies Map MF-88. 1957f, Preliminary geologic map of the Agathla Peak NE quadrangle, Arizona-Utah: U.S. Geol. Survey Mineral Inv. Field Studies Map MF-89. 1957g, Preliminary geologic map of the Agathla Peak SE quadrangle, Arizona: U.S. Geol. Survey Mineral Inv. Field Studies Map MF-90.

1957h, Preliminary geologic map of the Agathla Peak SW quadrangle, Arizona: U.S. Geol. Survey Mineral Inv. Field Studies Map MF-91. 